Burri, G. and HenkemeYer, H. (1972). In Parenteral Nutrition. 1st ed. P. 234. Churchill Livingstone. Edinburgh \& London.

Frost, P. M. and SMith, J. L. (1953). Metabolism 2, 529.

HADFIELD, J. (1975). Ann. roy. Coll. Surg. Engl. 53, 45.

Heatley, R. C. and Hughes, L. E. (1974). In Proceedings of the International Conference on Parenteral Nutrition. Montpellier, France.

Hinton, P., Allison, S. P., LitTlejohn, S. and Lloyd, J. (1973). Lancet ii, 218.

Ilexs, A. (1948). J. Amer. med. Ass. $138,500$.

KinneY, J. N., Duke, J. M., Long, C. L. and Gump, F. S. (1970). J. clin. Path. 23, Suppl. 4, 65 .

Law, D. K., Dudrick, S. J. and Abdou, N. I. (1973). Ann. intern. Med. 79, 545.

LEE, H A. (1974a). In Parenteral Nutrition in Acute Metabolic Illness. 1st ed. P. VII. Academic Press. London \& New York.

LEE, H. A. (1974b). Brit. J. Hosp. Med. 11.

LEE, H. A. (1974c). In Parenteral Nutrition in Acute Metabolic Illness. 1st ed. P. 314. Academic Press. London \& New York.

Moore, F. D. (1959). In Metabolic Care of the Surgical Patient. Saunders. Philadelphia.

Peaston, M. J. T. (1968). Hosp. Med. 2, 708.

TWEEDLE, D. (1975). Brit. J. Hospital Med. $13,81$.

Wretlind, A. (1974). In Parenteral Nutrition in Acute Metabolic Illness. 1st ed. P. 364. Academic Press. London \& New York.

\title{
ELECTRO-ENCEPHALOGRAPHY AND EVEREST CLIMBERS
}

\author{
LIEUTENANT-COLONEL P. ABRAHAM \\ M.R.C.Psych, D.T.M.\&H., R.A.M.C.
}

J. roy. Army med. Cps. 1978. 124, 84-87

Author's note: I had not appreciated from the limited translation kindly made available to me by Dr Charles F. Clark of Colorado that Dr Ryn made E.E.G. recordings before as well as after an expedition. As a result the following amendments are made to the above quoted paper:-

Page 84. Introduction, paragraph 2, line 1-Delete "This was also the first" and insert "It was also only the second". Line 2-After "off". add "The first report (Ryn 1970) described pathological tracings in 11 out of 30 climbers following an expedition". Line 3-for "the climbers" read "our climbers".

Page 86. Discussion, paragraph 3, line 5-After "seizures" add "(Scott 1978)".

Page 87. References-After "Prior etc" add "SCOTT, D. F. (1978). Photoconvulsive responses in patients over 30 years of age. Electroencep't. clin. Neurophysiol. (In press)". After "Ward etc" add--"Ryn, Z. (1970). Zaburzenia Psychiczne U Alpinistow W Warunkach Stresu Wysokogorskiego. Krakow". 